\title{
Evaluation of Some Inflammatory Biomarkers in Male Albino Wistar Rats Following Ingestion of Crude Oil and the Role of Bee Honey, Vitamins C and E
}

\author{
Sunday Otu Ita ${ }^{*}$, Edet Okon Akpanyung ${ }^{2}$, Akpoezoukumo Salima Robert ${ }^{1}$, \\ Esther Olusola Aluko1, Faith Okon Eseabasi', Michael Uwem Sunday-Essien' \\ ${ }^{1}$ Department of Physiology, Faculty of Basic Medical Sciences, University of Uyo, Uyo, Nigeria \\ ${ }^{2}$ Department of Biochemistry, Faculty of Basic Medical Sciences, University of Uyo, Uyo, Nigeria \\ Email: *uloro2003@yahoo.com
}

Received 22 June 2016; accepted 9 August 2016; published 12 August 2016

Copyright (C) 2016 by authors and Scientific Research Publishing Inc.

This work is licensed under the Creative Commons Attribution International License (CC BY). http://creativecommons.org/licenses/by/4.0/

(c) (i) Open Access

\begin{abstract}
Evaluation of some biomarkers of inflammation in male Albino Wistar rats following ingestion of Nigerian Bonny Light Crude Oil (NBLCO) and the effect of antioxidant supplementation was the focus of this study. Forty-eight adult male Albino Wistar rats weighing 150 - $180 \mathrm{~g}$ were randomly divided 8 per group into: group I (control) oral gavaged $3 \mathrm{ml} / \mathrm{kg}$ of normal saline; group II received $3 \mathrm{ml} / \mathrm{kg}$ of NBLCO; groups III, IV and V received in addition to $3 \mathrm{ml} / \mathrm{kg}$ of NBLCO $1 \mathrm{ml} / \mathrm{kg} \mathrm{vi}$ tamin C, vitamin E and $3 \mathrm{ml} / \mathrm{kg}$ of honey bee respectively; group VI received $3 \mathrm{ml} / \mathrm{kg}$ of honey. After 28 days of treatment, all animals were anaesthetized with chloroform and blood collected by cardiac puncture for analysis. Results showed that NBLCO administration significantly increased erythrocyte sedimentation rate and C-reactive protein while supplementation with antioxidant significantly reversed such effects $(p<0.05)$. NBLCO significantly reduced platelets and fibrinogen levels compared with the control group $(p<0.05)$. Interestingly, the vitamin supplementation significantly reduced platelets and fibrinogen levels compared to group II (NBLCO) $(p<0.05)$. Honey supplementation on the other hand significantly reduced platelets and fibrinogen compared to group II (NBLCO) $(p<0.05)$. From the results obtained it is concluded that ingestion of NBLCO has the potential to induce development and progression of inflammation but could substantially be mitigated by supplementation with antioxidant vitamins $\mathrm{C}, \mathrm{E}$ and honey.
\end{abstract}

\section{Keywords}

Crude Oil, Inflammation, Erythrocyte Sedimentation Rate, C-Reactive Protein, Antioxidants

\footnotetext{
${ }^{*}$ Corresponding author.
}

How to cite this paper: Ita, S.O., Akpanyung, E.O., Robert, A.S., Aluko, E.O., Eseabasi, F.O. and Sunday-Essien, M.U. (2016) Evaluation of Some Inflammatory Biomarkers in Male Albino Wistar Rats Following Ingestion of Crude Oil and the Role of Bee Honey, Vitamins C and E. Modern Research in Inflammation, 5, 55-62. http://dx.doi.org/10.4236/mri.2016.53006 


\section{Introduction}

Bioaccumulation of petroleum hydrocarbons has been reported to account for its hazardous effects by induction of oxidative stress leading to generation of free radicals [1] [2]. Such accumulation in turn causes a wide range of damage to critical cellular macromolecules including DNA, lipids and proteins [3], which is suspected to be mediated through lipid peroxidation [4]. Consequently, there is disruption in the functions of tissues and vital organs resulting in inflammatory-related disease conditions such as atherosclerosis. Compelling evidence from experimental researches has opened a window into the role of inflammation, the underlying cellular and molecular mechanisms that contribute to atherogenesis. Atherosclerosis is associated with deranged lipid metabolism [5] and micro-inflammation. In reference to lipid metabolism, cholesterol fractions are very important factor in the development of Cardiovascular Diseases (CVD); thus the ratio of triglyceride, Low Density Lipoprotein (LDL) and High Density Lipoprotein (HDL) are of immense importance. The classical concept of the pathogenesis of CVD, based on lipid and lipoproteins is highly associated with low HDL-C and elevated LDL-C. Elevated LDL-C is a central atherogenic lipoprotein class [6] in pathogenesis of atherosclerosis. There appears to exist a positive correlation between improper distribution of lipid, lipoprotein fractions and some predisposing factors such as genetic and environmental insults [7] including crude oil [8]; such insults can trigger off a cascade of inflammatory events associated with other agents like neutrophils, lymphocytes and platelets leading to atherosclerosis. Up regulation of adhesion molecules by blood leukocytes and inflammatory cytokines in endothelial cells is associated with the recruitment and accumulation of leukocytes and platelets on the endothelial cells lining the vasculature and in turn promote neutrophils, monocytes, lymphocyte, platelets and endothelial cell interactions [9]. Such cellular interactions between blood cells and endothelial cells may result in injury to the endothelium [9]. At high concentration, LDL particles could invade the endothelium and become oxidized by free radical agents. The oxidized LDL-C can then promote atherosclerosis. This is achieved by attracting other cells such as circulating mononuclear cells; lymphocyte and macrophages [10] with potentials to produce inflammatory chemicals cytokines, which are coupled with the capacity of macrophages to take up LDL and transform such into foam cells [11]. Furthermore, inflammatory cytokines are known to promote adhesion of platelets to the vascular endothelium, attracting leukocytes and indeed enhancing progression of plaque growth.

The concentration of oxidants in the body can be elevated by xenobiotic insults such as oil [12]. The presence of free radicals and Reactive Oxygen Species (ROS) is of the outmost importance in the pathogenesis of cellular dysfunction. The pathogenic mechanism is in one way or the other associated with inflammation, and is implicated in the pathogenesis of various cardiovascular diseases, neurodegenerative disorder, autoimmune disease, diabetes and cancer [13]-[15].

The consumption of foods and substances rich in anti-oxidants may protect against and prevent the pathogenesis of chronic inflammatory disorders. Amelioration or mitigation of the toxic effects of crude oil exposure would therefore require the search for agents capable of neutralizing the damaging effects of the released free radicals. Bee honey is such a natural agent as it is a reservoir for several important substances and these include mainly anti-oxidants [16]. Thus, the evaluation of some inflammatory biomarkers in male Wistar rats following ingestion of NBLCO and the role of antioxidants: bee honey, vitamins C and E, was therefore, the focus of this study.

\section{Materials and Methods}

\subsection{Chemicals and Drugs}

The crude petroleum used in this study was obtained from the EXXON/MOBIL laboratory, Ibeno, Nigeria. The bee honey was purchased from a local market situated in Uyo, Akwa Ibom State, Nigeria. The vitamin C tablets and vitamin E capsules were products of Softgel Healthcare Private Ltd, India.

\subsection{Experimental Animals}

Male Albino Wistar rats weighing between 150 - $180 \mathrm{~g}$ were obtained from the animal house of the Faculty of Basic Medical Sciences University of Calabar, Nigeria and were kept in a well-ventilated section of the Animal House in the Faculty of Basic Medical Science University of Uyo, Uyo Nigeria. They were allowed access to feed (Chow: vital feeds, Grand Cereals Ltd, Jos) and water ad libitum. The animals were allowed to acclimatize for a period of one week. 


\subsection{Experimental Design and Treatment of Animals}

A total of forty-eight (48) adult male Albino Wistar rats were randomly divided into six groups (group I, II, III, $\mathrm{IV}, \mathrm{V}$, and VI). Group I served as the control and was oral gavaged $3 \mathrm{ml} / \mathrm{kg}$ body weight of normal saline. Group II was oral gavaged $3 \mathrm{ml} / \mathrm{kg}$ body weight of NBLCO. This dose was calculated as $20 \%$ of the lethal dose $\left(\mathrm{LD}_{50}\right)$ of $14.14 \mathrm{ml} / \mathrm{kg}$, while groups III and IV in addition to $3 \mathrm{ml} / \mathrm{kg}$ body weight of NBLCO, were supplemented with $1 \mathrm{ml} / \mathrm{kg}$ body weight of vitamins $\mathrm{C}$ and $\mathrm{E}$ respectively. Group $\mathrm{V}$ in addition to $3 \mathrm{mi} / \mathrm{kg}$ body weight of NBLCO were supplemented with $3 \mathrm{ml} / \mathrm{kg}$ body weight of $50 \%$ bee honey solution. Group VI was oral gavaged $3 \mathrm{ml} / \mathrm{kg}$ body weight of $50 \%$ bee honey solution only. In all cases, the doses were based on the rat's most recently recorded body weight. The calculated volume in milliliter (ml) was applied daily for twenty eight (28) days. The experimental procedures involving the animals and their care were conducted in conformity with the approved guidelines by the Research and Ethical Committee of the Faculty of Basic Medical Sciences, University of Uyo, Uyo. Nigeria.

\subsection{Collection of Blood Sample for Analysis}

After the twenty eight (28) days of administration, the rats were anaesthetized with chloroform soaked in swap of cotton wool in a desiccator. Blood was collected by cardiac puncture with a $5 \mathrm{ml}$ sterile syringe and needle. The total volume of blood collected was $10 \mathrm{ml}$, which was divided into three portions in the ratio of 3:5:2. One portion (3 ml) was transferred into EDTA sample bottles for determination of platelet counts using automated hematology analyzer (BC-2300, Mindray, Germany). The second portion (5 ml) was transferred into plain sample bottles. This was allowed to stand for 2 hours to clot after which the blood sample were then spun with a table top centrifuge (RM-12 micro centrifuge, REMI, England) at 4000 rpm for 10 minutes. The serum was then carefully separated with the help of Pasteur pipette into clean labeled sample bottles and preserved at $-20^{\circ} \mathrm{C}$ until assayed for serum chemistry. The third portion of $2 \mathrm{ml}$ was used for the determination of ESR by Westegren method.

\subsection{Determination of C-Reactive Protein}

Serum C-reactive protein level was determined by the latex agglutination method [17] [18]. This was done using Biosystems C-reactive protein latex from Spain.

\subsection{Determination of Fibrinogen}

Centronic protein diagnostic kit from Germany was used for the determination of fibrinogen by turbidimetric immunoassay method as described by Etzel et al. [19].

\subsection{Lipid Profile}

The lipid components such as triglyceride and HDL-C were estimated in serum using standard kits supplied by Randox (UK), and Dialab (France) respectively. Total cholesterol, on the other hand was estimated using standard kits from Randox (USA).

\subsection{Calculation of Low Density Lipoproteins (LDL) and Very Low Density Lipoprotein (VLDL)}

The values of LDL and VLDL were obtained mathematically using the formulae below respectively [20].

$$
\begin{aligned}
& \mathrm{LDL}(\mathrm{mmol} / \mathrm{L})=\text { Total Cholesterol }-\mathrm{HDL}(\mathrm{mmol} / \mathrm{L})-\frac{\mathrm{TG}}{2.2}(\mathrm{mmol} / \mathrm{L}) \\
& \operatorname{VLDL}(\mathrm{mmol} / \mathrm{L})=\frac{\mathrm{TG}}{2.2}(\mathrm{mmol} / \mathrm{L})
\end{aligned}
$$

\subsection{Statistical Analysis}

Data were expressed as the mean \pm standard error of the mean and values of $p<0.05$ were considered significant. Statistical analysis was carried out using window SPSS package (SPSS 22.00 version). Data were analyzed 
using one way analysis of variance (ANOVA), results obtained were further subjected to test for least significant difference (LSD).

\section{Results}

\subsection{Effect of NBLCO, Honey, Vitamins C and E Administration on Erythrocyte Sedimentation Rate (ESR) and C-Reactive Protein (CRP) Levels in Rats}

The mean values of the ESR and CRP obtained are shown in Table 1. The results show that NBLCO significantly increased both ESR and CRP compared to group I (control) ( $<<0.05)$. Honey, vitamins C, and E supplementation significantly reduced ESR level compared to group II $(\mathrm{p}<0.05)$. While groups $\mathrm{V}$ (supplemented with honey) and VI (honey only) recorded significantly lower value of CRP compared to group II ( $<<0.05$ ), vitamins C and E supplementations did not alter CRP level significantly. ESR values in group III was significantly higher than group I but values obtained in groups IV, V and VI were not significantly different from group I.

\subsection{Effects of Nigerian Bonny Light Crude Oil and Some Antioxidant Supplementation on Platelet and Fibrinogen Levels in Rats}

The NBLCO in group II significantly decreased the mean platelets count and fibrinogen level compared to group I $(\mathrm{p}<0.05)$. Interestingly the values of these two parameters were significantly reduced in groups III-V supplemented with antioxidants as well as group VI which had honey only compared to group II $(\mathrm{p}<0.05)$, Table 2 .

\subsection{Effect of NBLCO and Antioxidant Supplementation on Lipid Profile}

The mean values of lipid profile obtained in the study are presented in Table 3. The results showed that NBLCO administration did not alter total cholesterol significantly compared with groups I (control) and V. The value of total cholesterol in group II (NBLCO) was however significantly higher than those of groups III, IV and VI.

Table 1. Erythrocyte sedimentation rate (ESR) and C-reactive protein (CRP) levels in control and test rats orally gavaged with NBLCO, Vitamin C, Vitamin E and pure honey for 28 days.

\begin{tabular}{ccc}
\hline Groups & ESR (mm/hr) & CRP (mg/dL) \\
\hline I (Control) & $1.83 \pm 0.31$ & $4.40 \pm 0.24$ \\
II (NBLCO) & $3.67 \pm 0.21^{\mathrm{a}}$ & $6.00 \pm 0.31^{\mathrm{a}}$ \\
III (NBLCO + Vit. C) & $2.33 \pm 0.56^{\mathrm{b}}$ & $5.33 \pm 0.33$ \\
IV (NBLCO + Vit. E) & $1.40 \pm 0.24^{\mathrm{b}}$ & $5.20 \pm 0.20$ \\
V (NBLCO + honey) & $1.00 \pm 0.00^{\mathrm{b}, \mathrm{c}}$ & $5.00 \pm 0.31^{\mathrm{b}}$ \\
VI (honey) & $2.00 \pm 0.41^{\mathrm{b}}$ & $5.60 \pm 0.40^{\mathrm{a}}$
\end{tabular}

Legends: ${ }^{\mathrm{a}}=$ significantly different from group I $(\mathrm{p}<0.05) ;{ }^{\mathrm{b}}=$ significantly different from group II $(\mathrm{p}<0.05){ }^{\mathrm{c}}=$ significantly different from group III $(\mathrm{p}<0.05)$.

Table 2. Platelet and fibrinogen levels in male Wistar rats exposed to NBLCO for 28 days.

\begin{tabular}{ccc}
\hline Groups & Platelets $\left(\times 10 / \mathrm{mm}^{3}\right)$ & Fibrinogen $(\mathrm{mg} / \mathrm{dl})$ \\
\hline I & $505.78 \pm 0.85$ & $458.75 \pm 0.82$ \\
II & $499.60 \pm 0.51^{\mathrm{a}}$ & $407.50 \pm 0.94^{\mathrm{a}}$ \\
III & $446.50 \pm 0.87^{\mathrm{ab}}$ & $390.00 \pm 3.78^{\mathrm{ab}}$ \\
IV & $419.67 \pm 1.76^{\mathrm{abc}}$ & $238.75 \pm 1.29^{\mathrm{abc}}$ \\
V & $372.75 \pm 1.49^{\mathrm{abcd}}$ & $248.75 \pm 2.06^{\mathrm{abcd}}$ \\
VI & $433.00 \pm 1.15^{\mathrm{abcd}}$ & $285.00 \pm 1.89^{\mathrm{abcde}}$
\end{tabular}

Legend: ${ }^{\mathrm{a}}=$ significantly different from group I $(\mathrm{p}<0.05){ }^{\mathrm{b}}=$ significantly different from group II $(\mathrm{p}<0.05){ }^{\mathrm{c}}=$ significantly different from group III ( $<<0.05) ;{ }^{\mathrm{d}}=$ significantly different from group IV $(\mathrm{p}<0.05) ;{ }^{\mathrm{e}}=$ significantly different from group $\mathrm{V}(\mathrm{p}<0.05)$. 
Table 3. Effect of NBLCO and antioxidant supplementation on lipid profile.

\begin{tabular}{cccccc}
\hline Groups & TC (mmol/L) & TG (mmol/L) & HDL (mmol/L) & LDL (mmol/L) & VLDL (mmol/L) \\
\hline Group I (control) & $3.70 \pm 0.12$ & $1.40 \pm 0.26$ & $2.96 \pm 0.02$ & $0.10 \pm 0.02$ & $1.68 \pm 0.05$ \\
Group II (NBLCO) & $3.90 \pm 0.10$ & $1.22 \pm 0.06$ & $2.54 \pm 0.10^{\mathrm{a}}$ & $0.81 \pm 0.17^{\mathrm{a}}$ & $1.77 \pm 0.05$ \\
Group III (NBLCO + Vit. C) & $3.35 \pm 0.12^{\mathrm{a}, \mathrm{b}}$ & $1.38 \pm 0.11$ & $2.45 \pm 0.12^{\mathrm{a}}$ & $0.28 \pm 0.17^{\mathrm{b}}$ & $1.52 \pm 0.05^{\mathrm{a}, \mathrm{b}}$ \\
Group IV (NBLCO + Vit. E) & $3.50 \pm 0.08^{\mathrm{a}, \mathrm{b}}$ & $1.52 \pm 0.07$ & $2.64 \pm 0.15^{\mathrm{a}}$ & $0.17 \pm 0.08^{\mathrm{b}}$ & $1.59 \pm 0.04^{\mathrm{b}}$ \\
Group V (NBLCO + honey) & $3.94 \pm 0.06^{\mathrm{c}, \mathrm{d}}$ & $1.64 \pm 0.12^{\mathrm{b}}$ & $2.78 \pm 0.10^{\mathrm{c}}$ & $0.08 \pm 0.09^{\mathrm{a}, \mathrm{b}}$ & $1.79 \pm 0.03^{\mathrm{c}, \mathrm{d}}$ \\
Group VI (honey) & $3.25 \pm 0.05^{\mathrm{a}, \mathrm{b}, \mathrm{e}}$ & $1.50 \pm 0.00$ & $2.50 \pm 0.04^{\mathrm{a}}$ & $0.04 \pm 0.01^{\mathrm{b}, \mathrm{e}}$ & $1.47 \pm 0.02^{\mathrm{a}, \mathrm{b}, \mathrm{e}}$ \\
\hline
\end{tabular}

Legend: ${ }^{\mathrm{a}}=$ significantly different from group I $(\mathrm{p}<0.05) ;{ }^{\mathrm{b}}=$ significantly different from group II $(\mathrm{p}<0.05) ;{ }^{\mathrm{c}}=$ significantly different from group III $(\mathrm{p}<0.05){ }^{\mathrm{d}}=$ significantly different from group IV $(\mathrm{p}<0.05) ;^{\mathrm{e}}=$ significantly different from group $\mathrm{V}(\mathrm{p}<0.05)$.

The NBLCO administration did not alter triglyceride level compared with groups I, III, IV and VI, but honey supplementation in group V significant raised triglyceride level compared with group II (NBLCO), $(\mathrm{p}<0.05)$.

NBLCO administration to group II animals significantly reduced HDL level when compared with the control group ( $<$ 0.05) but did not alter HDL-C significantly compared with groups III-VI. Groups III, IV and VI also recorded significantly low values when compared with the control $(\mathrm{p}<0.05)$. Honey supplementation in group $\mathrm{V}$ caused a significant increase when compared with group III $(\mathrm{p}<0.05)$.

Crude oil administration to group II animals caused a significant increase in LDL level when compared with groups I and V ( $<0.05)$. Supplementation with vitamins $\mathrm{C}$, E, and honey in groups III, IV and V respectively significantly reduced LDL-C compared with group II $(\mathrm{p}<0.05)$.

There was no significant change in VLDL-C values in groups II, IV and V when compared with group I. But the value of VLDL-C in group II was significantly higher than values for groups III, IV and VI ( $<<0.05)$.

\section{Discussion}

The present study has shown that ingestion of NBLCO results in a significant increase in the major biomarkers of inflammation such as ESR, and CRP. Additionally, administration of NBLCO significantly reduced fibrinogen. Significant elevation of low density lipoprotein cholesterol (LDL-C) following crude oil ingestion was also recorded. The data so reported are all suggestive of an inflammation induced possibly by NBLCO. Concomitant reduction in serum albumin level and elevated serum globulin could directly be linked with inflammatory reaction giving rise to the elevated ESR recorded, the ratio of albumin to globulin is important in determination of ESR as globulin is a known plasma protein fraction that contributes majorly to ESR elevation.

The significant increases in ESR and CRP as a consequent of NBLCO administration are suggestive of high inflammatory reactions occurring in the experimental animals. Although the relationship between the rats' adipose tissue and lipid profile was not investigated, suffice it to state that adipose tissue is a great reservoir of inflammatory factors, such as IL-6 and C-reactive protein (CRP), which also are well established markers of systemic inflammation [21].

The NBLCO administration has recently been reported to substantially interfere with immune function with high risks of inflammatory response as it elevated neutrophil, neutrophil-lymphocyte count ratio, globulin, IgG and IgM [22]. The administration of NBLCO significantly reduced platelet count, and platelets are known important component of active inflammatory reaction. Although platelet aggregation was not part of this study, the reduction in platelet so recorded could probably be due to the fact that greater percentage of platelet in circulation may have been mopped up into the inflammatory process itself thereby reducing its number in circulation. Another possibility for the reduction could be linked to the effect of NBLCO on haemopoietic systems, as toxic components of crude oil is reported to change the chemistry of the blood components and induce anaemia [23]. This it does by causing the bone marrow hypoplasia and interfered with platelets counts and other blood cells in the animals [23].

The two important biochemical indices that can be used to assess the health status of the liver are the serum levels of albumin and globulin. Albumin, which is synthesized in the liver, is a major protein that circulates in the blood stream [24]. The ingestion of NBLCO has been reported to be toxic to the hepatocellular elements; 
this might be the consequence of inflammation of the liver among other organs. Crude oil contains toxic compounds like polycyclic aromatic hydrocarbons (an important constituents of crude oil), which may have caused damages to the liver thereby interfering with the synthetic function of the liver.

The results of this study show inappropriate distribution of lipoprotein fractions in the rat. Triglyceride level was significantly reduced, which agrees with similar result reported by Ita and co-workers [25], who argued that low triglyceride will occur since the body tissues may likely resort to triglyceride as primary alternative energy substrate to hypoglycemic effect of NBLCO ingestion. The significantly higher levels of low density lipoprotein cholesterol (LDL-C) and lowered levels of high density lipoprotein cholesterol (HDL-C) recorded in this study is suggestive of interference with lipid metabolic process by the NBLCO. These results corroborate earlier studies where other petroleum products such as distillate aromatic extract gasoline [26] were reported to interfere with lipid metabolism. Such interference by NBLCO was reported to result in high serum total cholesterol, LDL-C and decreased HDL-C levels [8]. These results are suggestive of the risk of developing cardiovascular diseases (CVD) as earlier postulated by McKee and McKee [27], when crude oil is ingested or crude oil contaminated diet is consumed. At the present time, cardiovascular disease (CVD) is recognized as a chronic inflammatory condition of the vessel wall that result from the trans-endothelial passage of cholesterol-rich atherogenic apo- $\beta$ lipoproteins (VLDL-C, IDL, and LDL) from the plasma into the intima. The retention of cholesterol and LDL in the sub-endothelial space could attract infiltration of platelets and macrophages and perhaps other chemicals agents into the cells of the arterial wall as earlier reported by Williams and Tabas [28]. It can then be postulated that atherogenic potential of NBLCO might be accelerated by inflammatory tendencies of its toxicants. In line with this argument, Bendit [29] reported that injury to large blood vessels caused by toxic insult to vascular wall could trigger inflammatory response as inflammatory responses are essential components in the initiation and evolution of atherosclerosis. The development of atherosclerotic lesions, regardless of other risk factors is characterized by the disruption of the normal function of the endothelial cells, which may be due to high level of LDL with corresponding reduction in HDL level recorded in this study, and this could probably result in high yield of free radicals to cause damages. Chronic inflammation is directly associated with atherosclerosis following NBLCO ingestion; since exposure to environmental xenobiotic like polycyclic aromatic hydrocarbons (PAHs) has been reported to be among the risk factors for atherosclerosis [30] [31].

Interestingly, the administration of antioxidant agents such as honey, vitamins $\mathrm{C}$ and $\mathrm{E}$ have shown potentials of reversing the reported effects of NBLCO in rats by significantly reducing the level of these biomarkers for inflammation.

\section{Conclusion}

The results of the present study have also indicated that ingestion of NBLCO has significantly raised fibrinogen levels, which account for high ESR recorded in this study. Nigerian Bonny Light Crude Oil (NBLCO) caused reduction in platelet population, which probably could be due to platelet aggregation involved in the inflammatory process. Conclusively, the administration of NBLCO promotes inflammation in tissues as indicated by substantial elevated levels of Erythrocyte Sedimentation Rate (ESR) and C-Reactive Protein (CRP). The inflammation induced by Nigerian Bonny light crude oil could be mitigated or ameliorated with antioxidants supplementation.

\section{References}

[1] Val, A.L. and Almeida-Val, V.M.F. (1999) Effects of Crude Oil on Respiratory Aspects of Some Fish Species of the Amazon. In: Val, A.L. and Almeida-Val, V.M.F., Eds., Biology of Tropical Fishes, Instituto Nacional de Presquisas da Amazania (INPA), Manaus, 277-291.

[2] Achuba, F.I. and Osakwe, S.A. (2003) Petroleum Induced Free Radical Toxicity in African catfish (Clarias gariepinus). Fish Physiology and Biochemistry, 29, 97-103. http://dx.doi.org/10.1023/B:FISH.0000035905.14420.eb

[3] Souza, M.E., Tome, A.R. and Rao, V.S. (1999) Inhibition by the Bioflavonoid Ternation on Aflatoxin B1-Idncued Lipid Peroxidation in Rat Liver. Journal of Pharmacy and Pharmacology, 51, 125-129. http://dx.doi.org/10.1211/0022357991772222

[4] Halliweil, B. (1994) Free Radicals, Antioxidants and Human Disease. Curiosity, Cause or Consequence? Lancet, 334, 721-724. http://dx.doi.org/10.1016/S0140-6736(94)92211-X

[5] Wang, M. and Briggs, M.R. (2004) HDL: The Metabolism, Function \& Therapeutic Importance. Chemistry Review, 
104, 119-137. http://dx.doi.org/10.1021/cr020466v

[6] Graaf, J., van der Vleuten, G.M., Averst, E., Dallinga-Thie, M. and Stalenhoef, A.F.H. (2007) High Plasma Level of Remnant-Like Particles Cholesterol in Familial Combined Hyperlipidemia. The Journal of Clinical Endocrinology and Metabolism, 94, 1269-1275. http://dx.doi.org/10.1210/jc.2006-1973

[7] Dansky, H.M., Shu, P., Donavan, M., Montagno, J., Nagle, D.L., Smutko, S., Roy, N., Whiteing, S., Barrios, J., McBride, T.J., Smith, J.D., Duyk, G., Breslow, J.L. and Moore, K.J. (2002) A Phenotype-Sensitizing Apoe-Deficient Genetic Background Reveals Novel Atherosclerosis Predisposition Loci in the Mouse. Genetics, 160, 1599-1608.

[8] Ita, S.O., Udokang, N.E., Akpanyung, E.O. and Ekanem, A.L. (2011) An Evaluation of the Atherogenic Potential of Nigerian Bonny Light Crude Oil (NBLCO) in Rats. Instasci Journal of Medical Sciences and Clinical Research, 1, 48.

[9] Lavie, L. (2008) Intermittent Hypoxia: The Culprit of Oxidative Stress, Vascular Inflammation and Dyslipidemia in Obstructive Sleep Apnea. Expert Review of Respiratory Medicine, 2, 75-84. http://dx.doi.org/10.1586/17476348.2.1.75

[10] Powell, J.T. (1998) Vascular Damage from Smoking: Disease Mechanisms at the Arterial Wall. Vascular Medicine, 3, 21-28. http://dx.doi.org/10.1177/1358836X9800300105

[11] Morrow, D.A. and Ridker, P.M. (1999) Inflammation in Cardiovascular Disease. In: Topol, E., Ed., Textbook of Cardiovascular Medicine Updates, Lippomcott Williams and Wilkins, Cedar Knolls, 1-12.

[12] Di Toro, D.M., McGrath, J.A. and Hansen, D. (2000) Technical Basis for Narcotic Chemicals and Polycyclic Aromatic Hydrocarbon Criteria. I. Water and Tissue. Environmental Toxicology and Chemistry, 19, 1951-1970. http://dx.doi.org/10.1002/etc.5620190803

[13] Mates, J.M., Perez-Gomez, C. and De Castro, I.N. (1999) Antioxidant Enzymes and Human Diseases. Clinical Biochemistry, 32, 595-603. http://dx.doi.org/10.1016/s0009-9120(99)00075-2

[14] Kayode, A.A.A., Kayode, O.T. and Odetola, P.A. (2009) Anti-Ulcerogenic Activity of Two Extracts of Parquetina nigrescens and Their Effects on Mucosal Antioxidants Defense System on Ethanol-Induced Ulcer in Rats. Research Journal of Medicinal Plant, 3, 102-108. http://dx.doi.org/10.3923/rjmp.2009.102.108

[15] Vaghasiya, Y. and Chanda, S. (2010) Antimicrobial and Tree Radical Scavenging Activity of Different Solvent Extracts of Mangifera indica L. Seeds. Research Journal of Microbiology, 24, 217-223.

[16] Münstedt, K., Hoffmann, S., Hauenschild, A., Bülte, M., von Georgi, R. and Hackethal, A. (2009) Effect of Honey on Serum Cholesterol and Lipid Values. Journal of Medicinal Food, 12, 624-628. http://dx.doi.org/10.1089/jmf.2008.0188

[17] Singer, J.M., Plotz, C.M. and Elster, S.K. (1951) The Latex-Fixation Test III. Agglutination Test for C-Reactive Protein and Comparison with the Capillary Precipitin Method. American Journal of Clinical Pathology, 28, 611-617. http://dx.doi.org/10.1093/ajcp/28.6.611

[18] Hokoma, Y. and Nakamura, R.M. (1987) C-Reactive Protein: Current Status and Future Perspectives. Journal of Clinical Laboratory Analysis, 1, 15-27.

[19] Etzel, L.R., Strohbehn, R. and McVicker, J.K. (1997) The Development of an Automated Turbidimetric Immunoassay for Quantification of Bovine Serum Immunoglobulin G. American Journal of Veterinary Research, 58, 1201-1205.

[20] Friedewald, W.T., Levy, R.I. and Fredrickson, D.S. (1972) Estimation of Low-Density Lipoprotein Cholesterol in Plasma, without Use of Preparative Ultracentrifuge. Clinical Chemistry, 18, 499-502.

[21] Fantuzzi, G. (2005) Adipose Tissue, Adipokines, and Inflammation. Journal of Allergy and Clinical Immunology, 115, 911-919. http://dx.doi.org/10.1016/j.jaci.2005.02.023

[22] Ita, S.O., Dum-awara, B.L., Udofia, U. and Ojobo, E.E. (2015) Effects of Nigerian Bonny Light Crude Oil on Some Immunological Parameters: The Role of Antioxidant Vitamins C and E and Honey in Male Wistar Rats. Journal of Medical and Biological Science Research, 1, 71-77.

[23] Sudakov, K.V. (1992) Stress Postulate: Analysis from the Position of General Theory of Functional Systems. Pathophysiology of Experimental Therapeutic, 4, 86-89.

[24] Tietz, N.W. (1986) Fundamental of Clinical Chemistry. W.B. Saunders Company, Philadelphia, 723.

[25] Ita, S.O., Olubobokun, T.H., Benson, E.A., Antai, A.B. and Osim, E.E. (2013) Anti-Atherogenic Potentials of Vitamin $\mathrm{C}$ or E and Ministration against Ingested Nigerian Bonny Light Crude Oil (NBLCO) in Male Wister Rats. E3 Journal of Medical Research, 2, 0117-0122.

[26] Ubani, C.S., Joshua, P.E. and Umenwanne, V.C. (2009) Evaluation of Toxicological Implications of Ingestion Exposure to Gasoline in Mammals. Biokemistri, 21, 33-39.

[27] McKee, T. and McKee, R.I. (1999) Biochemistry. 2nd Edition, McGraw Hill, New York, 135-238.

[28] Williams, K.J. and Tabas, I. (2005) Lipoprotein Retention-And Clues for Atheroma Regression. Arteriosclerosis, 
Thrombosis \& Vascular Biology, 25, 1536-1540. http://dx.doi.org/10.1161/01.ATV.0000174795.62387.d3

[29] Benditt, E.P. (1974) Evidence for a Monoclonal Origin of Human Atherosclerotic Plaques and Some Implications. Circulation, 50, 650-652. http://dx.doi.org/10.1161/01.CIR.50.4.650

[30] Binkova, B., Strejc, P., Boubelik, O., Stavkova, Z., Chvatalova, I. and Sram, R.J. (2001) DNA Adducts and Human Atherosclerotic Lesions. International Journal of Hygiene and Environmental Health, 204, 49-54. http://dx.doi.org/10.1078/1438-4639-00072

[31] Izzotti, A., Cartiglia, C., Lewtas, J. and De Flora, S. (2001) Increased DNA Alterations in Atherosclerotic Lesions of Individuals Lacking the GSTM1 Genotype. The Federation of American Societies for Experimental Biology Journal, 15, 752-757. http://dx.doi.org/10.1096/fj.00-0312com

\section{Submit or recommend next manuscript to SCIRP and we will provide best service for you:}

Accepting pre-submission inquiries through Email, Facebook, LinkedIn, Twitter, etc.

A wide selection of journals (inclusive of 9 subjects, more than 200 journals)

Providing 24-hour high-quality service

User-friendly online submission system

Fair and swift peer-review system

Efficient typesetting and proofreading procedure

Display of the result of downloads and visits, as well as the number of cited articles

Maximum dissemination of your research work

Submit your manuscript at: http://papersubmission.scirp.org/ 